Article

\title{
A Systems Approach to Food Loss and Solutions: Understanding Practices, Causes, and Indicators
}

\author{
Monika Verma ${ }^{*}$, Christine Plaisier ${ }^{\dagger}$, Coen P. A. van Wagenberg ${ }^{\dagger}$ and Thom Achterbosch $(1)$ \\ Wageningen Economic Research, Wageningen University and Research, 2595 BM Den Haag, The Netherlands; \\ christine.plaisier@wur.nl (C.P.); coen.vanwagenberg@wur.nl (C.P.A.v.W.); thom.achterbosch@wur.nl (T.A.) \\ * Correspondence: monika.verma@wur.nl; Tel.: +31-070-335-8277 \\ + These authors contributed equally to this work.
}

Received: 30 November 2018; Accepted: 18 January 2019; Published: 22 January 2019

\begin{abstract}
Reasons behind food loss can be very specific for each product and supply chain stage but it is also affected by factors independent of the product and stage. This work focuses on such generic factors and develops a framework to analyze food loss as a systemic outcome. The framework highlights the interconnected nature of problem across supply chain stages and therefore emphasizes the need to look at the whole system instead of specific stages, when proposing solutions. Practices and underlying causes contributing to food loss are identified for each stage of the supply chain using a literature search. Deductive logic is used to fill the gaps where literature was found to be scarce, and to derive socio-economic indicators that signal the presence of identified causes. Using this framework, we propose a non-exhaustive list of 30 socio-economic indicators, which can signal the presence of the 22 practices and 60 causes associated with food loss in supply chains. This list can serve as a starting list for practitioners and policymakers to build on when analyzing food losses in supply chains in their region. We evaluate the framework using a field-study of a tomato supply chain in Nigeria, and conclude that it can be a useful tool to identify practices, causes, and indicators of food loss.
\end{abstract}

Keywords: systems approach; conceptual framework; food loss practices; food loss causes; food loss solutions; supply-chain stages; literature; socio-economic indicators; tomato; Nigeria

\section{Introduction}

Identifying reasons behind food loss is necessary for proposing solutions to combat the problem. These reasons differ according to the nature of the product and the stage of food supply chain, and are therefore more likely to be explored for specific combinations of products and supply chain stages. Looking at narrowly defined stand-alone product-stage combinations can give a comprehensive look into very specific causes but a broad general understanding of the issue in a macro sense can remain elusive. This work aims to promote a systemic rather than the stand-alone view of supply chains. This is done by showing how reasons for food loss are linked across stages of a single or more supply chains, and therefore proposed solutions should account for such inter-stage linkages. While the need for such holistic approaches accounting for dynamics of the whole supply chain instead of considering specific points in isolation is becoming apparent [1], this is precisely the kind of synergy that is often overlooked by taking a product specific approach to looking at food loss. The purpose of this study is therefore to develop a conceptual framework identifying root/structural causes of food loss with emphasis on across stage and across chains interrelations.

Inspiration for our framework comes from three concepts-micro, meso, and macro causes of food loss-as proposed by the High Level Panel of Experts report (HLPE) [2]. HLPE defines micro-level causes as actions or inaction of individual actors occurring at the same stage of supply chain where food is discarded, e.g., consumers not checking their refrigerators regularly to keep stock of what is 
available and discarding products that go bad. Meso-level causes refer to the way different actors are organized within or across different stages, e.g., lack of better transport infrastructure hinders how quickly and efficiently the suppliers and processors/retailers can conduct business. Macro-level causes are structural in nature, e.g., lack of institutional and legal capacity that could help coordinate actors to take actions and move towards better outcomes.

The use of terms micro-, meso-, and macro-level are difficult to explain to field actors, therefore we propose to use more comprehensible concepts of practices, causes, and indicators. In addition, HLPE does not give a clear link between the micro-, meso-, and macro-level causes. Building on HLPE, this work attempts to establish a more structured link between the practices, causes, and indicators. We start by identifying practices across supply chain stages, then identify causes underlying such practices, and finally we arrive at socio-economic indicators that can signal the presence of the identified causes in an economy.

While built as progressing from practices to indicators, given the strong links at each stage, this framework can as easily be used to look in the opposite direction: starting broad and filtering down to specifics. The information on socio-economic indicators is usually more readily available (from local governments and international bodies). Such information can be used to identify infrastructure categories that need more attention. The framework can then be used to list possible problems (practices and causes) associated with those infrastructural categories.

The benefit of using such a framework comes from being able to identify broad factors across supply chain stages applicable to most agricultural products. The link between indicators and food loss at more than a single supply chain stage implies, that addressing the causes associated with these indicators should, and could yield multi-stage benefits. Also, while important on their own, structural reasons of food loss can further be responsible for determining the presence and magnitude of loss at micro-level [2].

For practitioners, the framework emphasizes the need to be aware of the fact that their specific interventions might not yield the full potential effect because of the interrelations across supply chain stages and causes. For policy makers looking to make an impact on food loss, the proposed easier to observe socio-economic indicators can be used as red flags regarding the existence and severity of food loss in a region. Identifying indicators and seeing how many practices they can influence, made possible by viewing food loss as a result of the whole system, can help target efforts towards the practices and causes with links to multiple stages of supply chain. This work covers four supply chain stages: production and pre-harvest, harvest and initial on-farm handling, transportation and storage, and processing.

The article is structured as follows. Section 2 outlines the conceptual framework by means of a stylized example and identifies the components of the framework. Based on the details of Section 2, a synthesis of identified practices, causes, indicators, and their influence across stages is provided in Section 3. Section 4 looks at a specific supply chain-tomato supply chain in Nigeria-to assess whether the field data and observations support or refute the causes, practices, and indicators proposed under the systems framework approach. Finally, Section 5 gives the discussion and conclusions.

\section{Materials and Methods}

Section 2.1 lays out the conceptual framework. Section 2.2 identifies the most direct and clear links between indicators and causes.

\subsection{Conceptual Framework: A Systems Approach}

Figure 1a shows a stylized graphical representation of the conceptual framework. We list practices leading to food loss at each of the four above mentioned supply chain stages by asking: "what practices exist?" in the field, that contributes to food loss. Practices can be seen as actions or inactions on part of supply-chain participants. The practices are further explored in order to identify underlying causes that can help explain the existence of these practices by asking: "why do these practices exist?" For example, 
inadequate credit markets can help explain both, lack of proper storage as well as lack of proper harvesting techniques. Both questions above, are answered relying heavily, but not exclusively, on findings of the agronomy literature (see Section 2.2). For identifying indicators, given the absence of literature linking characteristics of supply chain to those of economy, deductive logic is used to see what kind of socio-economic characteristics of the economy can reflect the existence of the practices and causes. If they can help explain the existence of causes and practices behind food loss, efforts made towards improving these indicators should also contribute towards reduction in food loss. Therefore, the question asked to identify the indicators is: "how to reduce or minimize the loss resulting from these causes?", essentially asking what factors explain the existence of these causes and can therefore help reduce loss resulting from these causes.

Figure $1 \mathrm{~b}$ represents the complexity of the relationship between practices, causes, and indicators proposed in Figure 1a. For clarity of depiction, only two stages of the supply chain are shown, though the concept applies to all stages. The rectangular boxes called stage A and stage B in the figure depict the different supply chains stages. The red circles represent causes with ties to observed practices. Note that a single cause can contribute to losses in more than a one stage. For example, the lack of availability of credit can lead to the use of sub-quality seeds at the production stage, as well as to use of poor harvest equipment at the harvest and on-farm handling stage. Finally, the existence of causes is linked to indicators which can be grouped in four broad categories of infrastructure: knowledge, physical, financial, and institutional. These categories are chosen as most causes of food loss are believed to result from financial, knowledge (managerial, technical, organizational), institutional, and physical infrastructure bottlenecks [3]. We define the categories as follows. Knowledge infrastructure includes actors and process that determine how knowledge is created, shared, and changed/updated. In this context, knowledge infrastructure covers knowledge institutions, and extension and information networks. Physical infrastructure includes basic physical structures required for an economy to function and survive, such as transportation networks, power grid, sewage and waste disposal, etc. Institutions (both formal and informal), and institutional arrangements influencing rules and processes regarding how economy operates, form institutional infrastructure. State of the financial sector and its operations, and ease of credit access for all agents, forms the financial infrastructure.

The stylized representation helps to understand the food loss problem as a systems approach problem and therefore helps brings forth insights that otherwise escape scrutiny. Below are some examples of types of insights that can emerge from our stylized representation:

$>$ What kind of infrastructure is relevant for what stage? Different categories of infrastructure play a primary/substantial role in determining the state of food loss at different stages. For example, food loss at stage A is affected by causes (1) and (2), which are linked to knowledge, financial and institutional features of economy. Stage B practices are affected by causes (2), (3), and (4), and are thereby linked to physical and institutional infrastructure. As only the institutional category is shared across the two stages, addressing institutional infrastructure issues could help reduce food loss across both stages.

> Some practices might be easier to target than others In terms of the stylized figure above, reducing losses resulting from practice A1 calls for working on both knowledge and financial infrastructure issues. For A2, in addition to the aforementioned, we also need to pay attention to institutional factors. This increases the complexity and number of factors that an effective solution looking to reduce food loss at A2, would need to take into account, and it might therefore be harder to address. Only addressing knowledge and financial issues might not work because of institutional bottlenecks. As an example, cold storage facilities (physical) built without addressing electric grid and distribution issues (institutional and physical).

- Tackling certain causes may affect more practices and possibly yield higher reduction in food loss Addressing cause (1) affects both practices in Stage A and might therefore be more effective in reducing food loss in Stage A. Note that focusing on cause (1) to address losses in stage A, does not necessarily mean higher impacts in terms of food loss reduction: the impact also depends on magnitude 
issues, the initial states of food loss and different infrastructures in a region, and other country specific features.

$>$ Sustainability/acceptance - need to involve all actors Given the entangled nature of the problem and chains, the implementation success and propagation of any proposed solution hinges highly on its acceptability for all involved actors.

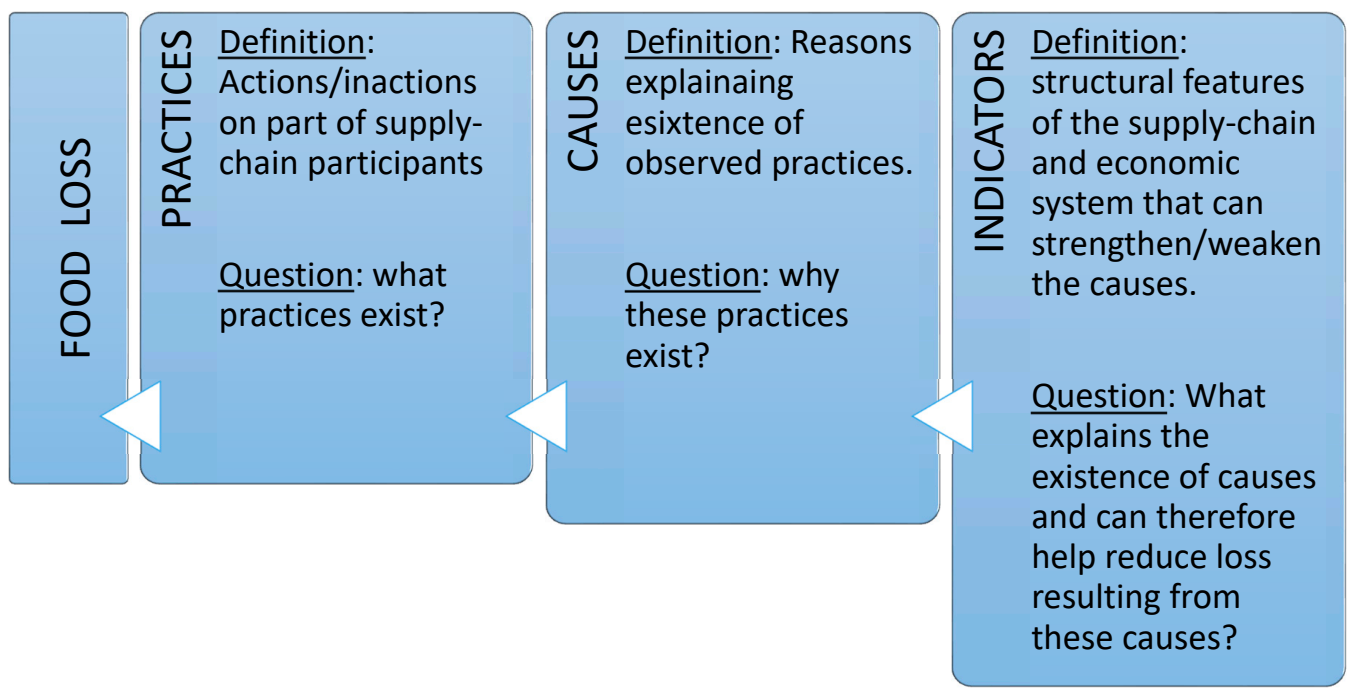

(a)

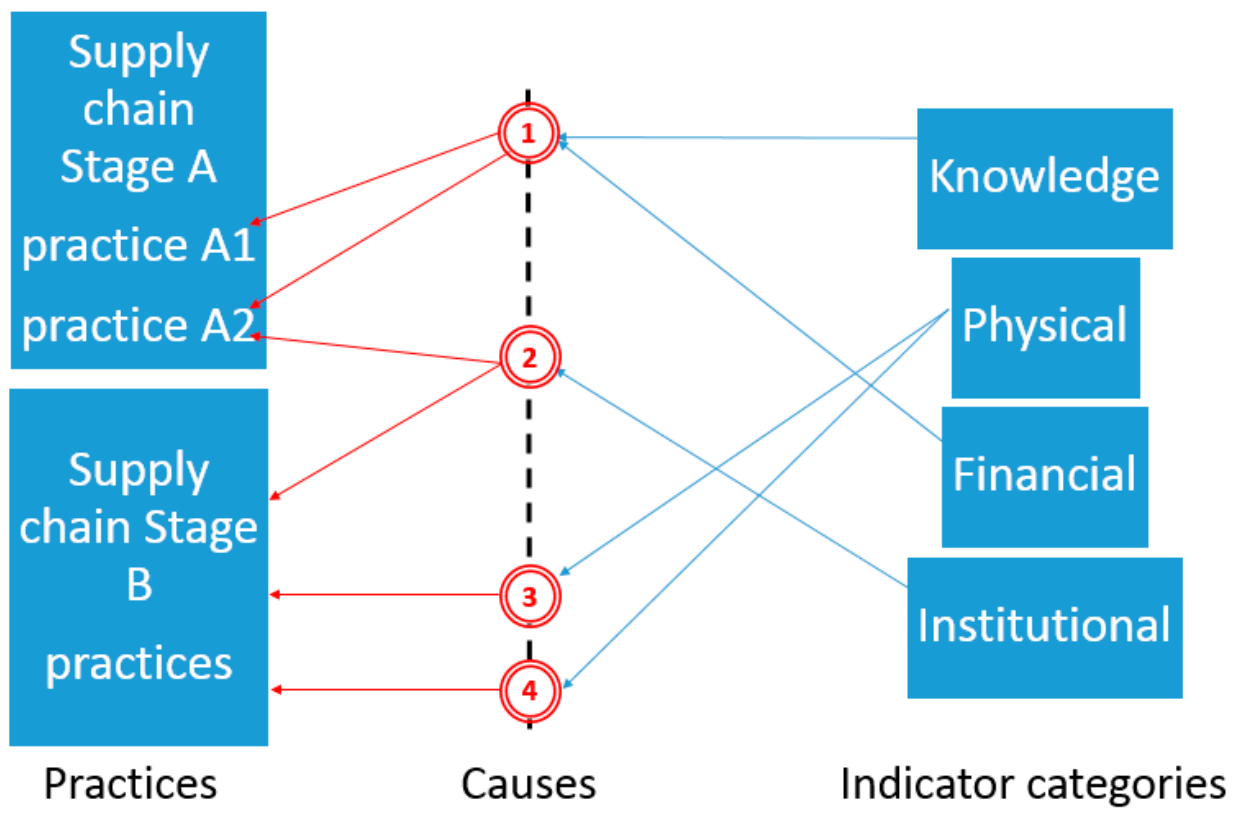

(b)

Figure 1. Stylized figure showing conceptual framework for the proposed systems approach. (a): link between the practices contributing to food loss, underlying causes, and identifying indicators. (b): complex nature of relationship between practices, causes, and indicators. A1 and A2 are examples of two different practices specific to the supply chain's stage A. The concentric red circles represent causes of food loss, not necessarily specific to any given stage. The figure depicts four such different causes. Knowledge, physical, financial, and institutional are the four types of infrastructure categories, to which the presence of the stage-generic causes can be linked. 


\subsection{Operationalizing the Framework: Identifying Practices and Causes, and Proposing Indicators}

\subsubsection{Production and Pre-Harvest Stage}

Production can be compromised in terms of quantity as well as quality even before it is harvested. While the focus on food loss is often restricted to post-harvest stages of supply chain, pre-harvest and harvest stages can and do influence the extent of post-harvest loss [4,5]. For example, wheat exposed to showers at a late stage of maturity is likely to have a shorter storage life irrespective of quality of storage facilities. Similarly, at least $5-10 \%$ of rice crop in Asia is lost annually to rodents [6] even before it is harvested, amounting to an equivalent of $11 \mathrm{~kg} /$ capita; which might become worse with more frequent outbreaks expected with climate change [7]. Also, if for any reason the product does not conform to certain standards for size, color, or shape, it might be rejected at a later stage [8]. For example, if a particular crop of mangoes fails to develop a required bright red hue, it is either rejected or fetches a much lower price. Note that this rejection can happen much later at the retail stage even though the cause-failure to develop the desired characteristics—occurred at the production/pre-harvest stage.

This is the stage of supply chain along with harvesting that is often overlooked in analysis of food loss [9] by economists; however, it is well explored by agronomists and agricultural engineers. Furthermore, in face of changing climate, we should expect the extent of such losses to rise $[10,11]$ and therefore the need for attention to this stage.

$>$ Practices contributing to pre-harvest loss

Pre-harvest losses could occur due to the presence or absence of practices ranging from choice of sub-optimal crop varieties and seeds [12,13] for local conditions; sub-optimal planting schedule [14,15]; to inefficient farm management practices regarding use of soil [16], water [17], nutrient [17,18]; and pest control [19].

Yet other causes that can explain losses at the production stage but do not have a bearing on agents' agricultural practices can be external factors like a bad weather spell [20-22]. While these losses are counted, the underlying causes are not a part of the food system. However, such causes can and do often lead to loss-averting behavior by agents, such as planting more to hedge against such risk of loss. Such causes should therefore be considered because their effect on agent behavior can be modified by means of policies and coordination, for example, crop insurance [23].

$>$ Causes underlying practices

Reasons that could influence the choice of crop variety and lead to planting of varieties unsuitable for local conditions could be many, such as lack of adequate information [24] and unavailability of the right seed varieties [25-27], either physically or economically.

Suboptimal farm management practices are also often seen as a result of lack of adequate information [28,29], unavailability of sufficient credit [26] to make changes towards better practices. The importance of such information in making critical and sustainable farming decisions is well understood in agronomy [30]. The scale of operation [25] and absence of clear regulations regarding farm management [27] can also influence how much time and effort a farmer spends on such activities.

Unforeseen consequences of government policies is another possible cause that can promote bad farm management practices (for example, using too much fertilizer) or the use of varieties unsuitable for local conditions. For example, providing free electricity for irrigation in India has promoted paddy cultivation supported by injudicious ground-water pumping in parts of the country, which would normally not grow the crop in absence of such a policy [31]. This is an example where the higher price for locally unsuitable variety along with government support for irrigation makes the adoption of the crop possible. Such crops are more susceptible to loss in event of failure/delay of the policy support they get. It is therefore important to pay attention to unintended consequence of a government support programs.

$>$ Indicators of causes of production and pre-harvest loss

Lack of adequate information and physical unavailability of varieties suitable to local conditions can arise from absence of regional agricultural research institutes and extension services or lack of their 
active participation in extension work. These, in turn, can result from neglecting agricultural sector and focusing more on industry in an attempt to grow faster. This is often the case with underdeveloped and developing economies.

Lack of economic access to suitable crop varieties could be a manifestation of lack of credit availability and immature state of financial infrastructure. The same two reasons explain equally well the use of suboptimal farm management practices. The small scale of operation (as is often the case in developing world) in absence of co-operatives and associations could result in a lack of incentives for investing in better farm practices. Such lack of organized efforts is also reflected in the inability of farmers to negotiate better contracts and prices for their produce, leading them to alternative hedging practices like planting more.

The above-mentioned indicators are often found to be poorly performing in developing countries, which are also the regions believed to be suffering more from problem of food loss in comparison to the developed world, which usually performs better on these indicators.

\subsubsection{Harvest and Initial On-Farm Handling Stage}

The next important stage in the food supply chain is harvesting including on farm sorting, threshing, and initial handling, described broadly as the "agricultural production" category in Gustavsson et al. [32]. Harvesting losses cause loss of output for not only current crops but may also have implications for quality and therefore buyers' acceptability of future crops, as suggested in Gulden et al. [33]. In terms of products, roots and tubers, and fruits and vegetables seem to be more susceptible to on farm losses than crops like cereals and oil seeds [32].

Unlike production losses (Section 2.2.1), cutting and threshing losses (not including losses from other initial handling processes like drying) seem not to significantly differ across traditional and mechanized supply chains (Figure 1, [34]). This seems to indicate that large-scale mechanization (as seen in agriculture in developed world) is not necessarily better when it comes to preventing harvesting losses.

$>$ Practices contributing to harvest loss

Actions at harvest stage can broadly be grouped into poor timing of harvest [35,36], poor methods and equipment choice for harvesting and initial handling [37], and inability to harvest or decision not to harvest the crop [38].

The time of harvest can affect the loss of agricultural produce in multiple ways. Apart from determining yield and quality of produce [39], harvest time also determines the moisture content of crop [40] and thereby its susceptibility to infestation. Similarly, maturity at the time of harvest can affect the extent of mold, insect, and aflatoxin contamination for grains [41,42]. Using contaminated grains as feed is also not feasible as it can lead to contaminated animal products [43]. Sometimes harvesting is delayed because the crop is left to dry in a field before it is harvested and often for longer than the recommended duration [41,44]. The timing of harvest of horticultural crops determines levels of ethylene, which affects its post-harvest shelf life (Chapter 2, [45]). Not only the maturity of horticultural products, but even the time of day chosen for harvest, can determine their post-harvest chemistry, and handling needs and in absence of the proper handling the likelihood of spoilage [4].

Timing, harvest method, and initial handling procedures can all affect the nutrient content (quality loss) of horticulture crops [46]. Improper harvest methods and initial handling can result in cuts, bruising, and surface abrasion in roots, tubers, fruits, and vegetables while harvesting leading to loss of water and nutrients (Chapter 2, [45]). Some examples of such practices are: use of mechanical combine harvester without specialized headers [47], particularly when crop is fallen or lodged; losses like spillage and heat injuries associated with mechanical harvesting [48]; failing to sort infected crop during harvesting often leading to contamination spreading to good harvest [49-51]; contamination during harvesting particularly from use of unhygienic equipment and unhygienic handling of dairy and slaughtered animals [52,53], often resulting in entire batches being discarded. Similarly, multiple or rough handling of horticultural produce can result in avoidable loss during 
harvest and/or transportation [48]. Note that while such factors are applied to both mechanical and manual harvesting, they are more relevant for mechanical ones as proper management of procedures is required (Chapter 2, [45]).

Inability to harvest or the decision to leave crops in field also contribute to harvest loss. Data from the U.S. shows that, on average, about $7 \%$ of all planted crops are not harvested, the same figure for fruits and vegetables stand at $6 \%$, and the numbers can be as high as $50 \%$ for some particularly bad years [8]. Moreover, one crop not harvested and left on field can provide food to rodent populations that can harm other standing crops [6].

$>$ Causes underlying practices

The reasons for sub-optimal harvest timing could be many: economic hardship [54] and need of cash [55], lack of adequate infrastructure and transport [55,56] (Chapter 13) for timely delivery of product to markets contributing to early harvest, labor shortage $[57,58]$ contributing to late or no harvest, lack of information on best practices [59], and credit constraints (can delay or push forward the time of harvest).

Mechanical inefficiency [60], often in combination with plant spacing, can also contribute to some amount of harvest lost. According to some estimates the harvest loss should be about $2-4 \%$ but is often as high as $10 \%$ or more (Figure 2, [2]), even in developed countries.

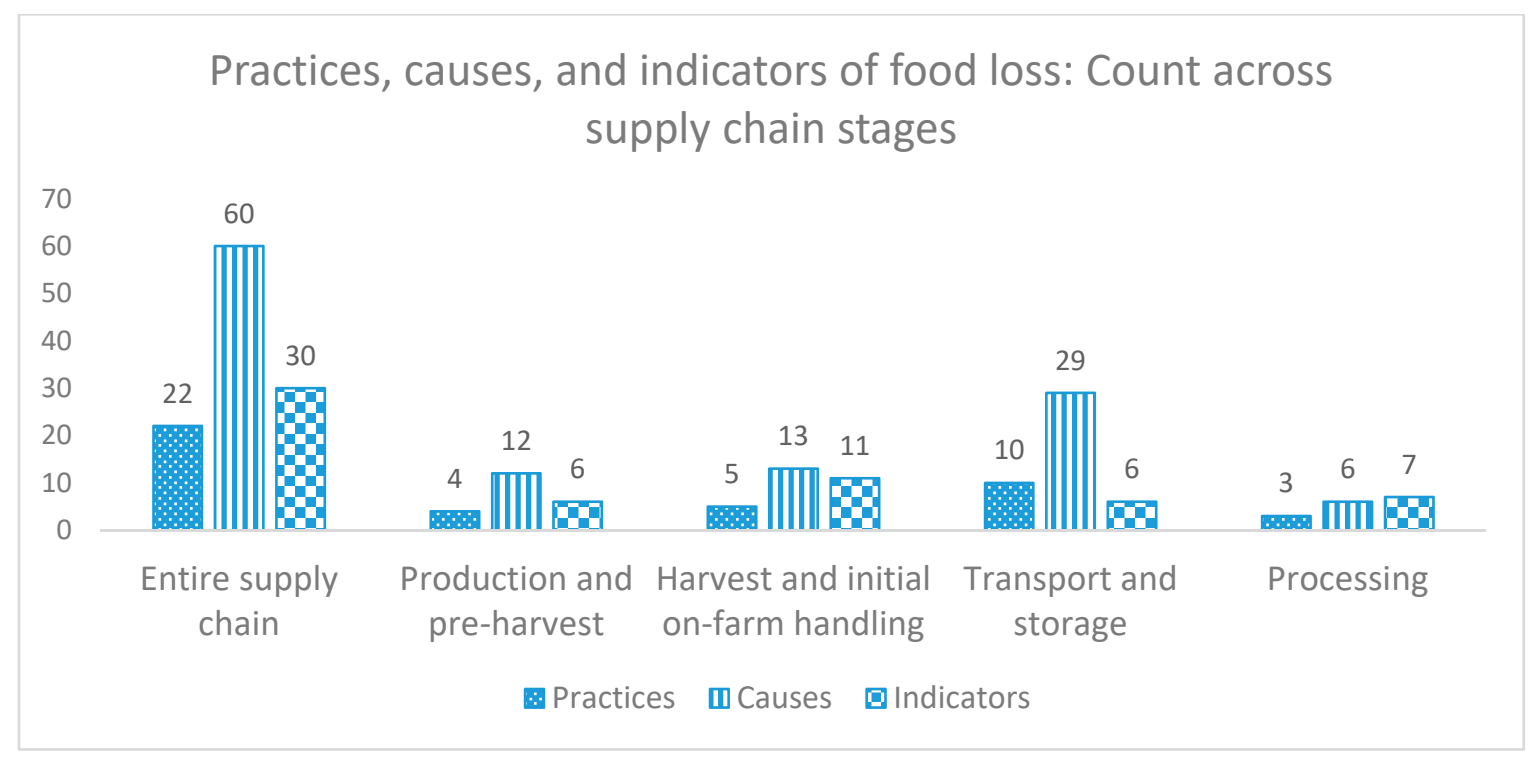

Figure 2. Practices, causes, and indicators' count by supply-chain stage.

Often times all or part of horticulture crop is not harvested or not sent forward into the supply chain owing to failed aesthetic standards [61], bad weather [62] or a plunge in market price for crop [63,64].

$>$ Indicators of causes of harvest and initial on-farm handling loss

From the analysis so far in Sections 2.2.1 and 2.2.2, it can be argued that within on-farm losses that are often clumped together in food loss analysis (Figure 2, [55]), the real difference between developed and developing regions comes not so much from harvesting losses but from initial handling and production practices. This seems to suggest that prevalence of traditional (less mechanized) harvesting cannot be taken as an indicator for the presence of large-scale harvesting loss.

Lack of means for dealing with economic hardship and need for cash leading to premature harvesting would be reflected in the absence of financial support system for farmers, which can in turn be measured by the absence of formal (agricultural development banks) and/or informal (co-operatives) channels of credit. Similarly, harvesting early to reach markets in time can be caught by measuring distance of markets from farms and the condition and extent of transport network. The need 
to reach distant markets could indicate a lack of local markets but also a shift towards a supermarket model of produce distribution. Agricultural labor shortage is again often a result of urbanization and migration of population towards urban areas. Early harvest due to lack of information on the best time to harvest is often due to lack of education and extension services. For example, education of farmer-a measure of ability of farmer to either already have the necessary information or be able to seek it-was the only variable that was found to be significant at $1 \%$ level for reducing losses for both wheat and rice in India in 2004 [65].

A decision not to harvest because of produce lacking in appearance can indicate a lack of alternative channels of disposal for fresh produce than the established supermarket chains, a lack of consumer awareness, or a lack of processing facilities to sell produce as canned or preserved. If crop is left on farm and not harvested because the farm price cannot cover production costs, it can indicate a lack of farm collectives or support programs and of storage and processing facilities.

\subsubsection{Transport and Storage Stage}

Transport and storage are important features of a modern food supply chain. Urbanization and the associated "supermarket revolution" [66] leads to changing nature of the food supply chain. This often results in increased distance and time between production and consumption [67], thereby increasing the demand and importance of transport and storage in food supply chain [68]. However, the improvements in efficiency come with a delay and products spend longer time in conditions not quite suitable for maintaining quality and/or quantity. Aulakh et al. [69] claim the loss during storage to be the highest in the supply chain, and as much as $50 \%$ to $60 \%$ of cereals stored can be lost due to technical inefficiencies [70]. Given the lack of clear chronological order between transport and storage, the two are combined for the purpose of this analysis.

In regions of world where transport and storage facilities are better, such losses are rare and come from equipment malfunctioning. Not surprisingly, the extent of losses are higher for developing regions of the world and, across products, losses are higher for fruits and vegetables owing to their highly perishable nature [32].

$>$ Practices contributing to transport and storage loss

Spoilage can occur during transportation itself owing to lack of temperature control, but also because of rough and multiple handling during loading and off-loading [4,71], and lack of proper storage [72] at the docks. Other factors that contribute to transport losses are theft [73], spillage, stress or heat injuries $[45,71,74]$ in fresh produce, as well as in livestock due to improper securing and packaging of cargo and longer time spent in transit [71]. As much as $16 \%$ of expected income from cattle is lost in Ghana and $45 \%$ of cattle in Ethiopia is affected during transport [2]. Loss of fresh produce is estimated to be between $30-50 \%$ in developing countries in the transport and storage stages [75].

Sometimes the produce is stored on-farm instead of being transported to market or is transported to an off-farm storage facility instead of a market. Grains stored at home openly or in traditional sacks [76,77]; tubers not sorted, cured, and treated before storage [78,79]; ineffective fumigation of grain silos [80,81]; and not using cold storage for horticultural crops all result in avoidable storage losses $[75,82]$. Traditional storage methods and equipment usually do not provide sufficient protection against temperature fluctuations and humidity. Better practices and technologies can reduce storage losses by almost $98 \%$ of those seen with traditional methods [70], irrespective of length of storage period. For example, Purdue improved crop storage (PICS) has been shown to reduce grain damage in terms of weight loss due to insects from over $40 \%$ to under $1 \%$ [83]. Unsanitary and unhygienic handling [22] during storage and transportation further adds to these losses.

Despite the use of the best storage facilities and practices, the losses can be considerable depending on product quality at time of harvest. This again points to the importance of link between product loss across stages and the need to tackle the problem in a system-wide context.

$>$ Causes underlying practices 
One reason behind transport losses is the high cost of transportation. Transport costs in Africa can be five times as high as those in Asia [84]. High transport costs render decent transport facilities outside the reach of small to medium scale farms [8], often making temperature-controlled transportation inaccessible to such farms. Cheaper but unreliable transport alternatives like donkeys, bicycles, or bad quality vehicles often result in delays in addition to those caused by bad road infrastructure and road blocks [82]. Both contribute toward a loss of quantity and quality. Transport losses are compounded because of improper cargo handling (unhygienic handling, piling, sitting on produce, etc.) often due to lack of knowledge about best practices [82]. Inefficient logistic planning further complicates matters (Chapter 2, [71]). Delays in reaching off-farm destinations could be caused not only for domestic produce but also for exported and imported products at the port of entry or exit. The important role that a cheaper and faster transport plays in spurring international trade is well-established [85].

Most storage loss, whether because of insects, pests, rodents, or temperature and moisture, can be attributed to poor storage conditions or equipment. For farmers in developing countries, cold storage for fresh produce is often not available or is a very expensive technology [82]. Given the fact that most such countries are geographically concentrated in tropical zones [75], high and variable temperatures accelerate the spoilage. Even when cold storage is available, mixing and piling together all different products at different stages of maturity results in losses [82] that can be easily avoided if this knowledge is to be made available to farmers. Furthermore, many developing countries experience an erratic, inconsistent power supply which renders any existing cold storage facilities ineffective [86-88]. While grains and tubers do not require cold storage, traditional storage methods often result in high losses mostly on account of lack of knowledge on best practices [22] such as drying and packaging.

$>$ Indicators of causes of transport and storage loss

Only purchasing the best equipment available is often not enough to reduce losses seen at the storage and transport for a host of factors as pointed out by [75]; using forklift/pallet trucks to avoid multiple handling also requires better surfaces for these machines to operate on, which cannot be achieved without planning infrastructural investments. Similarly, building cold storage without ensuring a regular and reliable power supply does not help. Therefore, developing low-cost technologies suited to local conditions [82] while working towards improving the local conditions should be a preferred approach. This requires promoting local research and extension efforts and building on the existing indigenous knowledge infrastructure alongside physical infrastructure. Both are severely lacking in the developing world.

Also, a lack of credit for investment and general apathy to agriculture can be seen in the inadequate (less than $5 \%$ of agricultural research funds worldwide) investment funds devoted to combat such losses (Chapter 1, [45]). Individual farmers do not have enough resources to make such investments on their own, while the absence of cooperatives rules out any collective organized effort.

Lack of credit, state of physical and knowledge infrastructure, and absence of collectives in presence of large share of small-scale farms are therefore good telltale signs of high transport and storage loss.

\subsubsection{Processing}

Processing can increase the shelf life of products by transforming it into canned and preserved varieties. In this way, this processing can be seen as one form of storage. In developing countries, edible food often ends up being lost due to the absence of processing facilities.

Food surplus in periods of excess supply or food that is slightly bruised/aesthetically unappealing can be processed for preservation and consumption at a later time.

An undesirable result of processing is often found to be a loss of vitamins and trace minerals [89], indicating that processing should not be a primary focus as a solution. Fortification can address this criticism but places a double burden on small-scale, capital-poor agents. Also, while processing serves the increasing demand for convenience food (pre-cut and ready to use produce), minimally processed produce does not last as long as intact produce (Chapter 2, [71]). This results in increased food waste at 
retail and consumer level. It therefore seems, that processing avoids food loss but adds to food waste and the reduction in food loss often comes at price of increased plastic/packaging waste [2].

$>$ Practices contributing to processing loss

Processing facilities in developing countries are mostly traditional for example fermentation, pickling (Chapter 3, [71]) and can often only handle small volumes [32]. Also, the produce preserved in traditional methods would often have limited local demand due to tastes and often fails to comply with food safety standards and other requirements such as labelling [87]. In addition, unsanitary and unhygienic handling of produce and dairy during the process can lead to easily avoidable losses $[52,53,87]$.

In the developed world, defects in packaging, such as wrong size, shape, and appearance make certain batches of processed product redundant [75]. Similarly, increased focus on achieving conformity results in excessive trimming of otherwise edible product. European Commission [90] estimated the processing sector in EU to be the second highest waste generator (19\%) in 2012 after consumers (53\%). Some estimates indicate that only $50 \%$ of the potato at the processing stage comes out in the form of a final output [91].

$>$ Causes underlying practices

As indicated in the previous section, losses in developing countries are often attributable to absent, inadequate, or limited capacity processing facilities [2]. The small scale of operation of individual farmers and the absence of coordinated collectives makes processing costs for individual farmers too high [87]. Processing facilities also requires investments in technical know-how capacity beyond the reach of small and oftentimes uneducated farmers. Also, in most developing countries, governments usually emphasize increased agricultural production rather than integrated efforts towards production and post-harvest management (Chapter 1, [71]).

The reasons for a high processing loss in the developed world on the other hand seems more to do with consumer attitudes towards acceptability [92] than technical or institutional limitations affecting the processing sector. Technical malfunctioning [2] can also result in processing loss.

$>$ Indicators of causes of processing loss

Capacity limits or non-existence of processing facilities, absence of organized community efforts, along with small scale farm operations and biased agricultural policy in favor of increased production are some indicators that can indicate the possible presence of big processing loss.

In the face of given consumer attitudes, absence of food-collectives, and possibility of legal obligation on food donations by processors can be indicative of the presence of processing losses.

While this section identifies only the most direct and clear links, a full matrix of the links, both direct and apparent, is available to interested readers upon request from the authors.

\section{Results}

This section builds on Section 2.2. and provides the information in tabular and graphical form. We present only the most direct and clear links. A full matrix of links is available upon request from the authors.

Figure 3 shows the number of indicators identified for the entire supply chain and for each of the individual four stages. In total, there are 30 indicators: 6 each relevant for production and pre-harvest, and transport and storage stages, 7 for processing stage, and 11 for harvest and initial on-farm handling stage. One important insight emerging from Figure 3 is that there is overemphasis on technological (knowledge and physical facilities) and financial bottlenecks in proposing solutions against food loss, but the often overlooked institutional infrastructure seems just as important. Collective efforts can yield benefits for small farmers as well as for the entire supply chain $[93,94]$. 


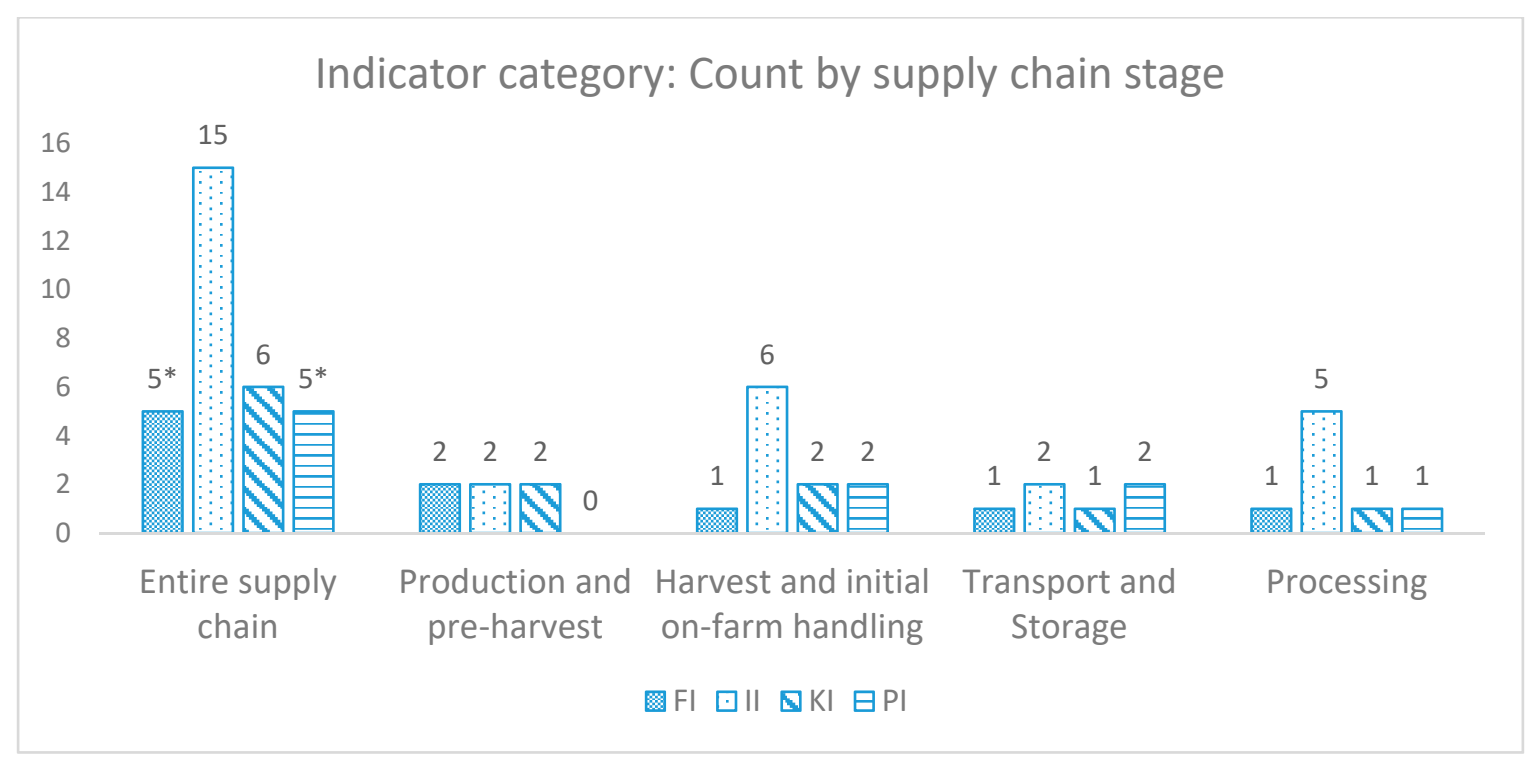

Figure 3. Indicator count by category and supply-chain stage. FI: financial infrastructure; II: institutional infrastructure; KI: Knowledge infrastructure; PI: physical infrastructure. $\left({ }^{*}\right) \mathrm{FI}$ and PI categories have one common indicator counted in both categories.

A list of the 30 indicators identified across the four stages is presented in Table 1.

Table 1. Infrastructural indicators proposed to assess the state of food loss in a region.

\begin{tabular}{|c|c|c|}
\hline Supply-chain Stage ${ }^{1}$ & Proposed Indicator & $\begin{array}{l}\text { Infrastructure Category of } \\
\text { Proposed Indicator }\end{array}$ \\
\hline \multirow{6}{*}{$\mathrm{PH}$} & Lack of general credit availability & FI \\
\hline & Immature state of general financial infrastructure & FI \\
\hline & $\begin{array}{c}\text { Ag policy: neglecting agricultural and focusing more on } \\
\text { industry/Injudicious ag support }\end{array}$ & II \\
\hline & Absence of co-operatives and farmer associations & II \\
\hline & $\begin{array}{c}\text { Absence of regional agricultural research institutes and extension } \\
\text { services }\end{array}$ & KI \\
\hline & $\begin{array}{c}\text { Lack of active participation of regional agricultural research } \\
\text { institutes in extension work }\end{array}$ & KI \\
\hline \multirow{11}{*}{$\mathrm{HH}$} & Absence of financial support system for farmers & FI \\
\hline & Distance of markets/seed centers from farms & II \\
\hline & Lack of local markets to sell product & II \\
\hline & Supermarket model of produce distribution & II \\
\hline & Urbanization and migration of population & II \\
\hline & $\begin{array}{l}\text { Lack of alternative demand channels of disposal of produce } \\
\text { (processing, storage, others) }\end{array}$ & II \\
\hline & Lack of farm collectives or support programs & II \\
\hline & Lack of education and extension services & KI \\
\hline & Lack of consumer awareness & KI \\
\hline & Transport network & PI \\
\hline & Lack of processing and storage facilities & PI \\
\hline \multirow{6}{*}{ TS } & Lack of credit for investment & FI \\
\hline & General apathy to agriculture & II \\
\hline & Absence of cooperatives & II \\
\hline & Lack of research and extension efforts & KI \\
\hline & Lack of technologies/facilities suited to local conditions & PI \\
\hline & Lack of infrastructural investments & PI \\
\hline \multirow{7}{*}{$\mathrm{P}$} & Absence of organized community efforts & II \\
\hline & Small-scale or non-diversified farm operations & II \\
\hline & Biased agricultural policy in favor of increased production & II \\
\hline & Absence of food-collectives & II \\
\hline & Legal obligation on food donations & II \\
\hline & Consumer attitudes & KI \\
\hline & Capacity limits or non-existence of processing facilities & $\mathrm{PI} / \mathrm{FI}$ \\
\hline
\end{tabular}

\footnotetext{
${ }^{1} \mathrm{PH}$ : production and pre-harvest; $\mathrm{HH}$ : harvest and initial on-farm handling; TS: transport and storage; P: processing.

${ }^{2}$ FI: financial infrastructure; II: institutional infrastructure; KI: knowledge infrastructure; PI: physical infrastructure.
} 
Some of the proposed indicators are specific to farming and agriculture, while others reflect the state of the wider economy. Some are connected to more than one stage (column 1, Table 1), and therefore seem to reappear in the list with slight differences. For example, community/co-operative efforts appear in all four stages, but it is considered a different indicator as community effort can take the form of different practices across different stages. Finally, the categorical classification (FI: financial infrastructure; II: institutional infrastructure; KI: knowledge infrastructure; PI: physical infrastructure) is also reported in column 3.

As the performance of a region on each indicator is seen as a signal regarding presence and severity of the food loss problem, the better the performance of a region in all categories, the less severe food loss is likely to be an issue for that region.

Figure 2 provides similar information for the practices and causes, as Figure 3 does for indicators. In all, there are 22 broad practice groups, 60 causes underlying the existence of such practices, and 30 indicators which can reflect the presence of these practices and causes in the supply chain.

Table 2 provides a list of all practices and causes by each stage. Existence of more causes (60) than practices further iterates the fact that each practice can be liked to multiple causes, and addressing a single cause might not yield desired reduction in food loss attributable to that practice. With multiple practices responsible for food loss, the complexity further increases. 
Table 2. Practices and causes identified in literature by each supply chain stage.

\begin{tabular}{|c|c|c|}
\hline Supply Chain Stage & Practices & Causes \\
\hline \multirow{4}{*}{ Production and pre-harvest } & Use of sub-optimal crop varieties and seeds & $\begin{array}{l}\text { Lack of information on varieties, physical unavailability of right seeds and varieties, economic } \\
\text { unavailability of right seeds and varieties, wrong market(price) signals }\end{array}$ \\
\hline & Sub-optimal planting schedule & Lack of information about planting; multiple or early planting due to economic hardship \\
\hline & Inefficient farm management & $\begin{array}{l}\text { Lack of information about farm management, credit unavailability, scale of farm operation, absence of } \\
\text { clear farm management regulations }\end{array}$ \\
\hline & External factors & $\begin{array}{l}\text { Bad weather (often leading to planting more to hedge), bad general economic conditions (often leading to } \\
\text { planting more to hedge) }\end{array}$ \\
\hline \multirow{5}{*}{ Harvest and initial on-farm handling } & Poor timing of harvest & $\begin{array}{l}\text { Economic hardship and need for cash, inadequate infrastructure and transport to ensure timely delivery, } \\
\text { labor shortage, lack of information about harvesting }\end{array}$ \\
\hline & Poor harvest methods and equipment & Lack of information about harvesting, mechanical inefficiency, credit unavailability \\
\hline & Poor on-farm initial handling, during and post-harvest & Lack of information \\
\hline & Inability to harvest & Labor shortage; bad weather \\
\hline & Decision to not harvest & Low market price, aesthetic product standard requirements, bad weather \\
\hline \multirow{10}{*}{ Transport and storage } & Lack of temperature control & Tropical climate, expensive storage technologies, erratic and unreliable power supply \\
\hline & Rough and multiple handling & Lack of knowledge about best practices, inefficient logistic planning, unreliable transport alternatives \\
\hline & Improper storage at docks & Expensive storage technologies, tropical climate, lack of knowledge about best practices \\
\hline & Theft and spillage & $\begin{array}{l}\text { Unreliable transport alternatives; inadequate road and rail infrastructure, road blocks; lack of knowledge } \\
\text { about best practices; inefficient logistic planning }\end{array}$ \\
\hline & Stress and heat injuries & $\begin{array}{l}\text { Unreliable transport alternatives; inadequate road and rail infrastructure, road blocks; lack of knowledge } \\
\text { about best practices; inefficient logistic planning; tropical climate; erratic and unreliable power supply }\end{array}$ \\
\hline & Long transit time & $\begin{array}{l}\text { Inadequate road and rail infrastructure, road blocks; unreliable transport alternatives; inefficient logistic } \\
\text { planning }\end{array}$ \\
\hline & Storing unsorted, untreated, uncured crop & Lack of knowledge about best practices \\
\hline & Insanitary and unhygienic storing & Lack of knowledge about best practices \\
\hline & Ineffective fumigation & Lack of knowledge about best practices, lack of technical capacity and availability of treatment \\
\hline & Ineffective storage sacks/silos & Tropical climate, expensive storage technologies, lack of knowledge about best practices \\
\hline \multirow{3}{*}{ Processing } & Traditional processing & Lack of or limited processing facilities, high costs of modern processing equipment \\
\hline & Unsanitary and unhygienic handling & Lack of information on best practices, lack of government efforts to improve postharvest practices \\
\hline & Discards due to product aesthetic standards & Consumer attitudes towards product acceptability, technical malfunctioning \\
\hline
\end{tabular}




\section{Framework Assessment: Comparison with Tomato Supply Chains in Nigeria}

Does the framework proposed in Section 2 help explain practices and causes seen in tomato supply chain in Nigeria? Data on tomato supply chain in Nigeria is gathered from two sources: a) responses of supply chain participants [95], and b) a non-exhaustive literature search on tomato losses in Nigeria. The subsections list the practices and causes of losses identified by literature and by field workshops for each stage.

\subsection{Practices, Causes, and Indicators Identified in Literature}

\subsubsection{Production and Pre-Harvest}

Tomatoes in Nigeria are grown outside and farmers do not control many variables that affect the quantity and quality of harvest, such as temperature, relative humidity, solar radiation and growing media [96], and soil moisture and presence of pathogens [97]. Farmers generally lack access to improved varieties and quality seeds [98].

Reliance on rainwater because of lack of proper irrigation [99] causes tomato production to be concentrated in the wet season. This causes seasonal production peak and low prices [99]. Heavy rainfall in wet season promotes growth of fungi [100,101], causing leaf diseases, such as wilt [102], blight [103], and defoliation and yellowing [100] of field crop, but also losses at later stages [101]. Recommended pesticides are not used because of high costs and lack of the necessary expertise to ensure their proper application [104]. Credit facilities needed to address such problems are often not available to farmers [101].

\subsubsection{Harvest and Initial On-Farm Handling}

Tomatoes are harvested half or fully ripe [105] including those intended for distant markets. Sometimes harvesting is done during the hotter moments of the day, which can result in heat stress to tomatoes [105]. Farmers use woven palm leaf collection baskets with hard and sharp edges for harvest collection and load these as fully as possible [99]. Baskets and tomatoes are not disinfected [99], and rotten fruits are mixed with healthy ones in baskets and in storage facilities, causing rapid spread of pathogens $[99,106]$. Most farmers store harvested tomatoes under tree shade without any further protection $[99,105]$. Without adequate storage facilities, pathogens can develop quickly [98]. Adequate storage facilities and post-harvest technologies are not used because farmers do not know about these options, have inadequate technological knowledge, have insufficient contact with extension workers, or the technologies are not available [98].

\subsubsection{Transport and Storage}

Cold storage facilities are often inadequate due to lack of electricity supply for farmers [107]. Farmers do not use appropriate post-harvest crop handling techniques, appropriate storage facilities are too expensive or not available, appropriate transport modes are not available, road conditions are bad, and market information and access are insufficient [106]. Fungicides are often too expensive to use during on-farm storage even if they were available [108], and farmers do not have access to credit facilities [101].

The raffia baskets are often used to move and store tomatoes without being disinfected between batches. A fungal spore left by one batch can easily infect subsequent batches [101]. Appropriate vehicles are often not available [98] and rail system cannot be used due to unusual delays [101]. Due to lacking adequate storage facilities at the farm [106], farmers need to move tomatoes quickly after harvest; therefore, all kinds of vehicles are used for transporting tomatoes to markets, many of them old and unfit [101]. Ropes used to secure baskets to such vehicles result in excessive local pressure and damage to tomatoes [109]. During transportation when baskets are overfilled or transporters use only leaves to separate the baskets [101], tomatoes are crushed [109]. In addition, flexible baskets forced into 
inadequate spaces in a vehicle, in conjunction with vibrations and impacts due to bad road surfaces, result in the compression and damage of the tomatoes [98,109].

Knowledge on the correct handling, storing, and transporting of tomatoes is lacking due to insufficient assistance and extension services, prevalence and perseverance of existing suboptimal practices, and a lack of interest from policy-makers [109]. Available training and research in the agricultural sector is inadequate [101]. Packaging containers such as plastic crates are not readily available, not available in sizes similar to the familiar raffia baskets, and are too expensive [110]. Additionally, many tomato fields are remote and are either not connected by good roads or the roads are in deplorable condition [99].

\subsubsection{Processing}

Sun-drying being simple and cheap is often used as a preservation technique though it reduces the ascorbic acid in tomatoes by almost 70\% [101]. Knowledge on correct preservation and processing is lacking, because available training and research in the agricultural sector is inadequate [101].

\subsection{Field Observations on Practices and Causes}

Supply chain participants (farmers, transporters, traders, and retailers) in the tomato supply chain in Nigeria were gathered in workshops with the aim to identify practices and causes for postharvest losses in their supply chain [95]. This section summarizes the results of these workshops.

\subsubsection{Production and Pre-Harvest}

Workshop participants identified seed quality, pest and disease occurrence, and weather fluctuations as main reasons for on-farm loss of tomatoes. Few farmers have irrigation facilities. The participants also reported high seasonality of tomato production leading to oversupply, low prices, and high losses in the peak season.

Farmers confirmed that high-quality seeds are either not available or not accessible due to lack of access to credit facilities. Lack of knowledge required for pest and disease control and unavailability of quality pesticide were also mentioned. The general lack of knowledge on good agricultural practices, both at farmer and extension worker level, was evident. Absence of farm records made the use of farm data for decision making and planning at the farm impossible. There is a general lack of producer cooperatives or collective action. Periods of over- and under-supply also usually result in produce not being harvested as costs often exceeding revenue. According to all participants, the focus of government policies is on other sectors (i.e., oil). No investments are made in agricultural research, nor in development and adoption of good agricultural practices.

\subsubsection{Harvest and Initial On-Farm Handling}

Workshop participants indicated that tomatoes are harvested at a late stage of maturity because the price is often set at the farm gate and the more mature the tomatoes the higher the price the farmer receives. In addition, participants mentioned a shortage of labor and that the available labor is often unskilled and unaware of proper harvesting techniques. Mechanization is not practical, as it requires high investments, which farmers cannot afford.

Use of raffia baskets for the tomato collection is widespread. According to the farmers, using plastic crates for tomatoes would not be possible because of the large scale of production would require a huge number of crates and it was unclear who should own the crates. They reported that investment needed towards introducing the plastic crates would be too high to bear for a single actor. The long geographic spread of the chain also poses a challenge of returning empty crates to their owners.

Beneath these practices is a lack of awareness and knowledge on good harvesting and handling techniques and on the subsequent consequences for the tomato quality. Besides, the lack of access to credit facilities hampers investments in better materials and equipment. 


\subsubsection{Transport and Storage}

All participants perceived transportation as a very serious cause of tomato loss. In addition, participants mentioned that the infrastructure is very poor, and many official and unofficial road controls lead to huge delays.

Transport fees are paid for each basket transported. The per basket mode of payment provides incentive for the transporters to take as many baskets as possible in a single trip. Given the flexibility of traditional raffia baskets this leads to tomato loss during transportation. Loading and off-loading is done in a very poor way and without much care. Furthermore, transporters are not held accountable for the condition and delivery time of tomatoes at their destination. This leaves no incentive for transporters to change the manner of their operations.

Most existing markets are without any shed, equipment, hygiene, or covering facilities for storing produce. For underlying causes, the participants point at general lack of knowledge on proper handling, lack of investments in improving the infrastructure, corruption and lack of security and control, and actors not being held accountable.

\subsubsection{Processing}

According to workshop participants, tomatoes are hardly ever processed to make tomato paste. There are a few companies willing to work with farmers producing tomatoes in open fields instead of green houses. Lack of cooperatives and collective action and the absence of crop scheduling hampers a stable supply of tomatoes to potential processing companies. Besides, there are doubts about the quality of tomatoes as a result of the low level of knowledge and application of good agricultural practices. For the drying practices, farmers lack the appropriate facilities and equipment as well as the knowledge and awareness on the appropriate drying techniques and hygiene practices. Participants also perceived the business environment to be marked by corruption and lack of transparency and suspected that it results in lack of interest from external investors to establish processing facilities in the country.

As can be seen, the conceptual framework lists many of the factors identified using field observations and associated literature of a specific case study without having to dig deeper into the specific case in question.

\section{Discussion and Conclusions}

The current work provides a conceptual framework to identify macro/structural factors responsible for food loss at various supply chain stages. According to the findings, poor institutional infrastructure, appears to be as prevalent a reason behind food loss as bad physical and financial infrastructures. This suggests that while technology-based solutions to food loss are important, the role of institutions deserves more attention. The framework further brings to the fore, the complex nature of the inter-connected reasons underlying food loss in supply chains, and emphasizes the need to see food loss as a systemic outcome.

The main advantages of this approach are:

- It can quickly help to identify problem areas in the supply-chain without the need to gather data on the whole supply chain of a product in any region. Once identified, the points of possible intervention should be explored further to devise the right solution.

- This manner of looking for solutions using a systems view lowers the risk of ineffective solutions and unintended negative consequences of proposed intervention.

- While food loss is hard to measure, data on indicators listed above are more easily available and comparable across regions.

- A solution towards bettering a given indicator affects not one but multiple causes associated with that indicator whether in the same or in different stages of the supply-chain; therefore, this approach can be used to identify solutions with most potential. Similarly, a given cause can be 
perpetuated due to bad performance on multiple indicators. Therefore, a single intervention aiming a single indicator/category would often fail to achieve its full potential in the presence of other bottlenecks in the system.

This work is not a substitute for quantifying the impact of various causes on extent of food loss. While an attempt is made to be thorough with the posed framework, the list of possible practices, causes, and indicators should not be treated as exhaustive or complete but as a starting base to build on. Also, while we could identify that Nigerian tomato supply chain seems to comply with the proposed framework, it should be tested for more products and regions. Furthermore, while the indicators are suggested because they are expected to be correlated to food losses, this remains to be confirmed. With limited existing work on evaluating the impact of improving infrastructure on food loss and waste [111], as a next step, more effort should be made to estimate the magnitude of effect on food loss from efforts towards improvement in these indicators.

We conclude that our framework can be a useful tool to identify socio-economic indicators that can signal the presence of food loss in supply chain stages. Furthermore, it can be used for linking practices in a given supply chain stage with their underlying causes that appear across multiple supply chain stages.

Author Contributions: Conceptualization and methodology, M.V.; validation, C.P. and C.P.A.v.W.; formal analysis, M.V., C.P., and C.P.A.v.W.; writing, M.V., C.P., C.P.A.v.W.; visualization, M.V., C.P.; project administration, M.V. and T.A.; funding acquisition, M.V. and T.A.; resources, T.A.

Funding: This research was funded by Dutch Ministry of Economic Affairs, grant number KB22-002-005.

Acknowledgments: The authors acknowledge use of Nigerian case-study results from projects funded by CGIAR-A4NH Flagship Food Systems for Healthier Diets for workshops in Nigeria, and from Multi-Donor Trust Fund for Sustainable Logistics (MDTD-SL) administrated by the World Bank. They also wish to thank the editor, the editorial staff, and the anonymous reviewers, for helping bring the article to its current state.

Conflicts of Interest: The authors declare no conflict of interest. The funders had no role in the design of the study; in the collection, analyses, or interpretation of data; in the writing of the manuscript, or in the decision to publish the results.

\section{References}

1. Affognon, H.; Mutungi, C.; Sanginga, P.; Borgemeister, C. Unpacking Postharvest Losses in Sub-Saharan Africa: A Meta-Analysis. World Dev. 2015, 66, 49-68. [CrossRef]

2. HLPE Food Losses and Waste in the Context of Sustainable Food Systems. The High Level Panel of Experts on Food Security and Nutrition; FAO: Rome, Italy, 2014; p. 117.

3. Kader, A.A. Increasing food availability by reducing postharvest losses of fresh produce. In Acta Horticulturae; International Society for Horticultural Science (ISHS): Leuven, Belgium, 2005; pp. 2169-2176.

4. Kader, A.A. Postharvest biology and technology: An overview. In Postharvest Technology of Horticultural Crops; University of California Agriculture and Natural Resources: Oakland, CA, USA, 2002; ISBN 978-1-879906-51-8.

5. Ippolito, A.; Nigro, F. Impact of preharvest application of biological control agents on postharvest diseases of fresh fruits and vegetables. Crop Prot. 2000, 19, 715-723. [CrossRef]

6. Singleton, G. Impacts of Rodents on Rice Production in Asia 2003. Available online: http:/ /books.irri.org/ 971220183X_content.pdf (accessed on 18 January 2019).

7. John, A. Rodent outbreaks and rice pre-harvest losses in Southeast Asia. Food Secur. 2014, 6, 249-260. [CrossRef]

8. Gunders, D. Wasted: How America Is Losing Up to 40 Percent of Its Food from Farm to Fork to Landfill; Natural Resources Defense Council: New York, NY, USA, 2012.

9. IFPRI Toward a sustainable food system: Reducing food loss and waste. In Global Food Policy Report; IFPRI: Washington, DC, USA, 2016; p. 10.

10. Gourdji, S.; Läderach, P.; Valle, A.M.; Martinez, C.Z.; Lobell, D.B. Historical climate trends, deforestation, and maize and bean yields in Nicaragua. Agric. For. Meteorol. 2015, 200, 270-281. [CrossRef]

11. Lesk, C.; Rowhani, P.; Ramankutty, N. Influence of extreme weather disasters on global crop production. Nature 2016, 529, 84-87. [CrossRef] [PubMed] 
12. Bandyopadhyay, R.; Kumar, M.; Leslie, J.F. Relative severity of aflatoxin contamination of cereal crops in West Africa. Food Addit. Contam. 2007, 24, 1109-1114. [CrossRef] [PubMed]

13. Öztürk, F.P.; Kaçal, E.; Sarısu, H.C.; Karamürsel, D.; Emre, M. Economic evaluation of preharvest and harvest losses in “0900 ziraat” sweet cherry cultivar. In Acta Hortic; International Society for Horticultural Science (ISHS): Leuven, Belgium, 2010; pp. 261-267.

14. Scott, R.K.; English, S.D.; Wood, D.W.; Unsworth, M.H. The yield of sugar beet in relation to weather and length of growing season. J. Agric. Sci. 1973, 81, 339-347. [CrossRef]

15. Shivrain, V.K.; Burgos, N.R.; Gealy, D.R.; Smith, K.L.; Scott, R.C.; Mauromoustakos, A.; Black, H. Red Rice (Oryza sativa) Emergence Characteristics and Influence on Rice Yield at Different Planting Dates. Weed Sci. 2009, 57, 94-102. [CrossRef]

16. George, T.; Magbanua, R.; Garrity, D.P.; Tubana, B.; Quiton, J. Rapid Yield Loss of Rice Cropped Successively in Aerobic Soil. Agron. J. 2002, 94, 981-989. [CrossRef]

17. Jatav, K.S.; Agarwal, R.; Singh, R.; Shrivastava, M. Growth and Yield Responses of Wheat [Triticum aestivum L.] to Suboptimal Water Supply and Different Potassium Doses. J. Funct. Environ. Bot. 2012, 2, 39. [CrossRef]

18. Dangler, J.M.; Locascio, S.J. External and Internal Blotchy Ripening and Fruit Elemental Content of Trickle-irrigated Tomatoes as Affected by N and K Application Time. J. Am. Soc. Hortic. Sci. 1990, 115, 547-549.

19. Oerke, E.-C. Crop losses to pests. J. Agric. Sci. 2006, 144, 31-43. [CrossRef]

20. Thompson, L.M. Weather Variability, Climatic Change, and Grain Production. Science 1975, 188, 535-541. [CrossRef] [PubMed]

21. Lusk, J.L.; Tack, J.; Hendricks, N.P. Heterogeneous Yield Impacts from Adoption of Genetically Engineered Corn and the Importance of Controlling for Weather. Agric. Product. Prod. Behav. 2018.

22. Abass, A.B.; Ndunguru, G.; Mamiro, P.; Alenkhe, B.; Mlingi, N.; Bekunda, M. Post-harvest food losses in a maize-based farming system of semi-arid savannah area of Tanzania. J. Stored Prod. Res. 2014, 57, 49-57. [CrossRef]

23. Hill, R.V.; Viceisza, A. A field experiment on the impact of weather shocks and insurance on risky investment. Exp. Econ. 2012, 15, 341-371. [CrossRef]

24. Gardas, B.B.; Raut, R.D.; Narkhede, B. Modeling causal factors of post-harvesting losses in vegetable and fruit supply chain: An Indian perspective. Renew. Sustain. Energy Rev. 2017, 80, 1355-1371. [CrossRef]

25. Ghimire, R.; Wen-chi, H.; Shrestha, R.B. Factors Affecting Adoption of Improved Rice Varieties among Rural Farm Households in Central Nepal. Rice Sci. 2015, 22, 35-43. [CrossRef]

26. Shiferaw, B.; Kebede, T.; Kassie, M.; Fisher, M. Market imperfections, access to information and technology adoption in Uganda: Challenges of overcoming multiple constraints. Agric. Econ. 2015, 46, 475-488. [CrossRef]

27. Floro IV, V.O.; Labarta, R.A.; López-Lavalle, L.A.B.; Martinez, J.M.; Ovalle, T.M. Household Determinants of the Adoption of Improved Cassava Varieties using DNA Fingerprinting to Identify Varieties in Farmer Fields: A Case Study in Colombia. J. Agric. Econ. 2017, 69, 518-536. [CrossRef]

28. Bozoğlu, M.; Ceyhan, V. Measuring the technical efficiency and exploring the inefficiency determinants of vegetable farms in Samsun province, Turkey. Agric. Syst. 2007, 94, 649-656. [CrossRef]

29. Wilson, P.; Hadley, D.; Asby, C. The influence of management characteristics on the technical efficiency of wheat farmers in eastern England. Agric. Econ. 2001, 24, 329-338. [CrossRef]

30. Tanaka, D.L.; Krupinsky, J.M.; Liebig, M.A.; Merrill, S.D.; Ries, R.E.; Hendrickson, J.R.; Johnson, H.A.; Hanson, J.D. Dynamic cropping systems: An adaptable approach to crop production in the Great Plains. Agron. J. 2002, 94, 957-961. [CrossRef]

31. Planning Commission Report of the High Level High Level Expert Group on Water Logging in Punjab; Government of India: New Delhi, India, 2013; p. 95.

32. Gustavsson, J.; Cederberg, C.; Sonesson, U. Global Food Losses and Food Waste: Extent, Causes and Prevention; Study Conducted for the International Congress Save Food! at Interpack 2011, [16-17 May], Düsseldorf, Germany; Food and Agriculture Organization of the United Nations: Rome, Italy, 2011.

33. Gulden, R.H.; Shirtliffe, S.J.; Thomas, A.G. Harvest losses of canola (Brassica napus) cause large seedbank inputs. Weed Sci. 2003, 51, 83-86. [CrossRef]

34. Hodges, R.J.; Buzby, J.C.; Bennett, B. Postharvest losses and waste in developed and less developed countries: Opportunities to improve resource use. J. Agric. Sci. 2011, 149, 37-45. [CrossRef] 
35. Bednarz, C.W.; Shurley, W.D.; Anthony, W.S. Losses in Yield, Quality, and Profitability of Cotton from Improper Harvest Timing. Agron. J. 2002, 94, 1004-1011. [CrossRef]

36. Philbrook, B.D.; Oplinger, E.S. Soybean Field Losses as Influenced by Harvest Delays. Agron. J. 1989, 81, 251-258. [CrossRef]

37. Price, J.S.; Hobson, R.N.; Neale, M.A.; Bruce, D.M. Seed Losses in Commercial Harvesting of Oilseed Rape. J. Agric. Eng. Res. 1996, 65, 183-191. [CrossRef]

38. Kantor, L.S.; Lipton, K.; Manchester, A.; Oliveira, V. Estimating and Addressing America's Food Losses. Food Rev. 1997, 20, 2-12.

39. Dag, A.; Kerem, Z.; Yogev, N.; Zipori, I.; Lavee, S.; Ben-David, E. Influence of time of harvest and maturity index on olive oil yield and quality. Sci. Hortic. 2011, 127, 358-366. [CrossRef]

40. Buckmaster, D.R.; Heinrichs, A.J. Losses and Quality Changes during Harvest and Storage of Preservative-treated Alfalfa Hay of Varying Moisture Content. Trans. ASAE 1993, 36, 349-353. [CrossRef]

41. Kaaya, A.N.; Warren, H.L.; Kyamanywa, S.; Kyamuhangire, W. The effect of delayed harvest on moisture content, insect damage, moulds and aflatoxin contamination of maize in Mayuge district of Uganda. J. Sci. Food Agric. 2005, 85, 2595-2599. [CrossRef]

42. Hell, K.; Fandohan, P.; Ranajit, B.; Kiewnick, S.; Sikora, R.; Cotty, P.J. Pre- and postharvest management of aflatoxin in maize: An African perspective. In Mycotoxins: Detection Methods, Management, Public Health and Agricultural Trade; Leslie, J.F., Bandyopadhyay, R., Visconti, A., Eds.; CABI: Wallingford, UK, 2008; pp. 219-229. ISBN 978-1-84593-082-0.

43. Prandini, A.; Tansini, G.; Sigolo, S.; Filippi, L.; Laporta, M.; Piva, G. On the occurrence of aflatoxin M1 in milk and dairy products. Food Chem. Toxicol. 2009, 47, 984-991. [CrossRef] [PubMed]

44. Alakonya, A.E.; Monda, E.O.; Ajanga, S. Effect of Delayed Harvesting on Maize Ear Rot in Western Kenya. Am.-Eurasian J. Agric. Environ. Sci. 2008, 4, 372-380.

45. Kader, A.A.; Rolle, R.S. The role of Post-Harvest Management in Assuring the Quality and Safety of Horticultural Produce; FAO Agricultural Services Bulletin; Food and Agriculture Organization of the United Nations: Rome, Italy, 2004; ISBN 978-92-5-105137-5.

46. Lee, S.K.; Kader, A.A. Preharvest and postharvest factors influencing vitamin C content of horticultural crops. Postharvest Biol. Technol. 2000, 20, 207-220. [CrossRef]

47. Hobson, R.N.; Bruce, D.M. PM-Power and Machinery: Seed Loss when Cutting a Standing Crop of Oilseed Rape with Two Types of Combine Harvester Header. Biosyst. Eng. 2002, 81, 281-286. [CrossRef]

48. Kitinoja, L.; Kader, A.A. Small-Scale Postharvest Handling Practices: A Manual for Horticultural Crops, 5th ed.; Postharvest Horticulture Series; Postharvest Technology Research and Information Center, University of California-Davis: Davis, CA, USA, 2015.

49. Mutiga, S.K.; Were, V.; Hoffmann, V.; Harvey, J.W.; Milgroom, M.G.; Nelson, R.J. Extent and Drivers of Mycotoxin Contamination: Inferences from a Survey of Kenyan Maize Mills. Phytopathology 2014, 104, 1221-1231. [CrossRef] [PubMed]

50. Kabak, B.; Dobson, A.D.W.; Var, I. Strategies to Prevent Mycotoxin Contamination of Food and Animal Feed: A Review. Crit. Rev. Food Sci. Nutr. 2006, 46, 593-619. [CrossRef] [PubMed]

51. Choudhary, A.K.; Kumari, P. Management of Mycotoxin Contamination in Preharvest and Post Harvest Crops: Present Status and Future Prospects. J. Phytol. 2010, 2, 37-52.

52. Oliver, S.P.; Jayarao, B.M.; Almeida, R.A. Foodborne Pathogens in Milk and the Dairy Farm Environment: Food Safety and Public Health Implications. Foodborne Pathog. Dis. 2005, 2, 115-129. [CrossRef] [PubMed]

53. Sofos, J.N. Challenges to meat safety in the 21st century. Meat Sci. 2008, 78, 3-13. [CrossRef] [PubMed]

54. Sunderlin, W.D.; Resosudarmo, I.A.P.; Rianto, E.; Angelsen, A. The Effect of Indonesia's Economic Crisis on Small Farmers and Natural Forest Cover in the Outer Islands 2000. Available online: http: / / dlc.dlib.indiana.edu/dlc/bitstream/handle/10535/4358/Sunderlin-the-effect-of-indonesias-economiccrisis-on-small-farmers-and-natural-forest-cover-in-the-outer-islands.pdf? sequence=1\&isAllowed=y (accessed on 18 January 2019).

55. Godfray, H.C.J.; Beddington, J.R.; Crute, I.R.; Haddad, L.; Lawrence, D.; Muir, J.F.; Pretty, J.; Robinson, S.; Thomas, S.M.; Toulmin, C. Food Security: The Challenge of Feeding 9 Billion People. Science 2010, 327, 812-818. [CrossRef] [PubMed]

56. Sudheer, K.P.; Indira, V. Post Harvest Technology of Horticultural Crops; New India Publishing: New Delhi, India, 2007; ISBN 978-81-89422-43-1. 
57. Richards, T.J.; Patterson, P.M. Hysteresis and the Shortage of Agricultural Labor. Am. J. Agric. Econ. 1998, 80, 683-695. [CrossRef]

58. Guan, Z.; Wu, F.; Roka, F.; Whidden, A. Agricultural Labor and Immigration Reform. Choices 2015, 30, 1-9.

59. Aguilar-Gallegos, N.; Muñoz-Rodríguez, M.; Santoyo-Cortés, H.; Aguilar-Ávila, J.; Klerkx, L. Information networks that generate economic value: A study on clusters of adopters of new or improved technologies and practices among oil palm growers in Mexico. Agric. Syst. 2015, 135, 122-132. [CrossRef]

60. Casamali, B.; Williamson, J.G.; Kovaleski, A.P.; Sargent, S.A.; Darnell, R.L. Mechanical Harvesting and Postharvest Storage of Two Southern Highbush Blueberry Cultivars Grafted onto Vaccinium arboreum Rootstocks. HortScience 2016, 51, 1503-1510. [CrossRef]

61. Stuart, T. Waste: Uncovering the Global Food Scandal; W. W. Norton: New York, NY, USA, 2009; ISBN 978-0-393-07735-3.

62. Dawson, A. Unprecedented Year for Potatoes as Thousands of Acres go Unharvested; Manit. Co-Oper: Winnipeg, MB, Canada, 2018.

63. Vietnamnews Price Drop Forces Farmers to Leave Vegetables Unharvested. Available online: http: / / vietnamnews.vn/society / 424383/price-drop-forces-farmers-to-leave-vegetables-unharvested.html (accessed on 5 January 2019).

64. Freshplaza Argentina: Apples are Left Unharvested due to Low Prices. Available online: www.freshplaza.com/ article/2190490/argentina-apples-are-left-unharvested-due-to-low-prices / (accessed on 5 January 2019).

65. Basavaraja, H.; Mahajanashetti, S.B.; Udagatti, N.C. Economic Analysis of Post-harvest Losses in Food Grains in India: A Case Study of Karnataka. Agric. Econ. Res. Rev. 2007, 20, 117-126.

66. Reardon, T.; Gulati, A. The Supermarket Revolution in Developing Countries: Policies for Competitiveness with Inclusiveness. Available online: https:/ /ideas.repec.org/p/fpr/polbrf/2.html (accessed on 22 January 2019).

67. Thyberg, K.L.; Tonjes, D.J. Drivers of food waste and their implications for sustainable policy development. Resour. Conserv. Recycl. 2016, 106, 110-123. [CrossRef]

68. Seto, K.C.; Ramankutty, N. Hidden linkages between urbanization and food systems. Science 2016, 352, 943-945. [CrossRef]

69. Aulakh, J.; Regmi, A.; Fulton, J.R.; Alexander, C. Estimating Post-Harvest Food Losses: Developing a Consistent Global Estimation Framework; Agricultural and Applied Economics Association: Washington, DC, USA, 2013.

70. Kumar, D.; Kalita, P. Reducing Postharvest Losses during Storage of Grain Crops to Strengthen Food Security in Developing Countries. Foods 2017, 6, 8. [CrossRef]

71. Rolle, R.S.; Asian Productivity Organization, Food and Agriculture Organization of the United Nations (Eds.) Postharvest Management of Fruit and Vegetables in the Asia-Pacific Region; Asian Productivity Organization, Food and Agricultural Organization: Tokyo, Japan; Rome, Italy, 2006; ISBN 978-92-833-2369-3.

72. Salin, V.; Nayga, R.M. A cold chain network for food exports to developing countries. Int. J. Phys. Distrib. Logist. Manag. 2003, 33, 918-933. [CrossRef]

73. Sheahan, M.; Barrett, C.B. Review: Food loss and waste in Sub-Saharan Africa. Food Policy 2017, 70, 1-12. [CrossRef] [PubMed]

74. Lara, L.J.; Rostagno, M.H. Impact of Heat Stress on Poultry Production. Animals 2013, 3, 356-369. [CrossRef] [PubMed]

75. IMECHE Global Food: Waste Not, Want Not; Institute of Mechanical Engineers: London, UK, 2013; p. 36.

76. Thamaga-Chitja, J.M.; Hendriks, S.L.; Ortmann, G.F.; Green, M. Impact of maize storage on rural household food security in Northern Kwazulu-Natal. J. Consum. Sci. 2004, 32. [CrossRef]

77. Tefera, T. Post-harvest losses in African maize in the face of increasing food shortage. Food Secur. 2012, 4, 267-277. [CrossRef]

78. Parmar, A.; Hensel, O.; Sturm, B. Post-harvest handling practices and associated food losses and limitations in the sweetpotato value chain of southern Ethiopia. NJAS Wageningen J. Life Sci. 2017, 80, 65-74. [CrossRef]

79. Ray, R.C.; Ravi, V. Post harvest spoilage of sweetpotato in tropics and control measures. Crit. Rev. Food Sci. Nutr. 2005, 45, 623-644. [CrossRef] [PubMed]

80. Bell, C.H. Fumigation in the 21st century. Crop Prot. 2000, 19, 563-569. [CrossRef]

81. Flinn, P.W.; Hagstrum, D.W.; Reed, C.; Phillips, T.W. United States department of agriculture-Agricultural Research Service stored-grain areawide Integrated Pest Management program. Pest Manag. Sci. 2003, 59, 614-618. [CrossRef] [PubMed] 
82. Ait-Oubahou, A. Postharvest technologies in sub-saharan Africa: Status, problems and recommendations for improvements. In Acta Hortic; International Society for Horticultural Science (ISHS): Leuven, Belgium, 2013; pp. 1273-1282.

83. Ng'ang'a, J.; Mutungi, C.; Imathiu, S.M.; Affognon, H. Low permeability triple-layer plastic bags prevent losses of maize caused by insects in rural on-farm stores. Food Secur. 2016, 8, 621-633. [CrossRef]

84. Worldbank (Ed.) Reshaping Economic Geography; World Development Report; World Bank: Washington, DC, USA, 2009; ISBN 978-0-8213-7607-2.

85. Hummels, D.L.; Schaur, G. Time as a Trade Barrier. Am. Econ. Rev. 2013, 103, 2935-2959. [CrossRef]

86. Saurav, S.; Potti, R. Cold Chain Logistics in India: A Study. In Innovative Solutions for Implementing Global Supply Chains in Emerging Markets; IGI Global: Hershey, PA, USA, 2016; pp. 159-172.

87. Mhazo, N.; Mvumi, B.M.; Nyakudya, E.; Nazare, R.M. The status of the agro-processing industry in Zimbabwe with particular reference to small- and medium-scale enterprises. Afr. J. Agric. Res. 2011, 7.

88. Walters, S.A.; Groninger, J.W.; Oval Myers, J. Rebuilding Afghanistan's agricultural economy: Vegetable production in Balkh Province. Outlook Agric. 2012, 41. [CrossRef]

89. Schroeder, H.A. Losses of vitamins and trace minerals resulting from processing and preservation of foods. Am. J. Clin. Nutr. 1971, 24, 562-573. [CrossRef] [PubMed]

90. FUSIONS Estimates of European Food Waste Levels; Food Use for Social Innovation by Optimising Waste Prevention Strategies; European Commission: Brussels, Belgium, 2016.

91. Higgins, K.T. Flash Dryers and Potato Waste. Available online: https://www.foodengineeringmag.com/ articles/83689-flash-dryers-and-potato-waste (accessed on 29 November 2018).

92. Neff, R.A.; Spiker, M.L.; Truant, P.L. Wasted Food: U.S. Consumers' reported awareness, attitudes, and behaviors. PLoS ONE 2015, 10, e0127881. [CrossRef] [PubMed]

93. ABB Ability System 800xA for world's Largest Milk Cooperative Amul in India-ABB Process Control Solutions for Food and Beverage Manufacturing (ABB Process Automation and Control Solutions by Industry). Available online: https://new.abb.com/control-systems/industry-specific-solutions/foodbeverage/system-800xa-for-world-s-largest-milk-cooperative-amul-india (accessed on 28 November 2018).

94. Jamal, R. Saving Milk from Spoilage in Rural India. Available online: https://www.theguardian.com/ sustainable-business/saving-milk-rural-india-business-sustainable (accessed on 28 November 2018).

95. Plaisier, C.; Sibomana, M.; van der Waal, J.; Clercx, L.; van Wagenberg, C.P.A.; Dijkxhoorn, Y. Approach for Designing Context-Specific, Locally Owned Interventions to Reduce Postharvest Losses: Case Study on Tomato Value Chains in Nigeria. Sustainability 2019, 11, 247. [CrossRef]

96. Tilahun, S.; Do, S.P.; Mu, H.S.; Cheon, S.J. Review on factors affecting the quality and antioxidant properties of tomatoes. Afr. J. Biotechnol. 2017, 16, 1678-1687.

97. Okoli, C.A.N.; Erinle, I.D. Factors responsible for market losses of tomato fruits in the Zaria area of Nigeria. J. Hortic. Sci. 1989, 64, 69-71. [CrossRef]

98. Akangbe, J.A.; Ogundiran, T.J.; Komolafe, S.E.; Ifabiyi, J.O.; Ajibola, B.O. Tomato farmers adoption level of postharvest value addition technology and its constraints in Surulere Area of Oyo State, Nigeria. J. Agric. Soc. Res. 2014, 14, 91-97.

99. Arah, I.K.; Kumah, E.K.; Anku, E.K.; Amaglo, H. An Overview of Post-Harvest Losses in Tomato Production in Africa: Causes and Possible Prevention Strategies. J. Biol. Agric. Healthc. 2015, 5, 78-88.

100. Wokoma, E.C.W. Preliminary Report on Diseases of Tomato in Choba, Rivers State. J. Appl. Sci. Environ. Manag. 2008, 12. [CrossRef]

101. Etebu, E.; Nwauzoma, A.B.; Bawo, D.D.S. Postharvest spoilage of tomato (Lycopersicon esculentum Mill.) and control strategies in Nigeria. J. Biol. 2013, 3.

102. Ganiyu, S.A.; Popoola, A.R.; Enikuomehin, O.A.; Bodunde, J.G. Influence of grafting on growth and yield performance of two tomato cultivars grown in open field in Nigeria. J. Plant Pathol. 2018, 100, 43-50. [CrossRef]

103. Ekundayo, E.A.; Ekundayo, F.O.; Osinowo, I.A. Antifungal activities of Trichoderma viride and two fungicides in controlling diseases caused by Sclerotium rolfsii on tomato plants. Adv. Appl. Sci. Res. 2015, 6, 12-19.

104. Umeh, V.C.; Onukwu, D. Development of environmentally-friendly tomato insect pest control options under tropical conditions. J. Veg. Sci. 2005, 11, 73-84. [CrossRef] 
105. Olayemi, F.; Adegbola, J.; Bamishaiye, E.; Daura, A. Assessment of post-harvest challenges of small scale farm holders of tomotoes, bell and hot pepper in some local government areas of Kano State, Nigeria. Bayero J. Pure Appl. Sci. 2011, 3. [CrossRef]

106. Adepoju, A.O. Post-harvest losses and welfare of tomato farmers in Ogbomosho, Osun state, Nigeria. J. Stored Prod. Postharvest Res. 2014, 5, 8-13.

107. Olosunde, W.A.; Aremu, A.K.; Onwude, D.I. Development of a solar powered evaporative cooling storage system for tropical fruits and vegetables. J. Food Process. Preserv. 2016, 40, 279-290. [CrossRef]

108. Animashaun, M.O.; Bishop, C.F.H.; Cullum, J. The use of hot water treatment for the control of Alternaria alternata in tomato. In Proceedings of the Acta Horticulturae; International Society for Horticultural Science (ISHS): Leuven, Belgium, 2016; pp. 233-240.

109. Raji, O.A.; Oriola, O.K. Packaging and handling methods as sources of mechanical damage in tomatoes in transit. J. Eng. Appl. Sci. 2007, 2, 1450-1454.

110. Idah, P.A.; Ajisegiri, E.S.A.; Yisa, M.G. Fruits and Vegetables Handling and Transportation in Nigeria. AU J. Technol. 2007, 10, 175-183.

111. Rosegrant, M.W.; Magalhaes, E.; Valmonte-Santos, R.A.; Mason-D'Croz, D. Returns to Investment in Reducing Postharvest Food Losses and Increasing Agricultural Productivity Growth. Available online: http:/ /www.ifpri. org/publication/returns-investment-reducing-postharvest-food-losses-and-increasing-agricultural (accessed on 22 January 2019).

(C) 2019 by the authors. Licensee MDPI, Basel, Switzerland. This article is an open access article distributed under the terms and conditions of the Creative Commons Attribution (CC BY) license (http://creativecommons.org/licenses/by/4.0/). 